\title{
Hubungan Diagnosa Keperawatan Terhadap Kinerja Perawat
}

\author{
Lili Evalina
}

\author{
lili.evalina@gmail.com
}

\section{Latar Belakang}

Diagnosa keperawatan atau nurshing diagnose adalah langkah lanjutan yang dilakukan oleh perawat setelah mendapatkan gambaran klinis. Diagnosa ini bertujuan untuk mengetahui adanya permasalahan kesehatan baik secara aktual maupun potensial dalam respon individu di berbagai lingkup. Seorang perawat dapat membuat dan mengeluarkan diagnosa keperawatan karena perawat yang bersangkutan sudah memiliki lisensi serta kompetensi khusus yang sesuai dengan pekerjaanya sebagai seorang perawat. Dengan adanya lisensi dan kompetensi yang dimiliki oleh seorang perawat tersebut, maka seorang perawat juga memilikki kemampuan untuk mengubah status kesehatan kliennya setelah klien tersebut melalui beberapa proses untuk mendapatkan hasil kesehatannya. Meski demikian, setiap pekerjaan harus dilakukan dengan teliti dan penuh kehati - hatian, begitu pula bagi seorang perawat. Dalam mengeluarkan diagnosa keperawatan, perawat juga harus memastikan bahwa diagnosanya tersebut berdasar, meski baru sebuah diagnosa.

Berdasarkan pemaparan mengenai penjelasan apa itu diagnosa keperawatan sendiri, maka dari sana sudah dapat terlihat apa hubungan dari diagnosa keperawatan dengan kinerja perawat itu sendiri. Kinerja menurut Mangkunegara (2015) adalah suatu hasil yang didapatkan dari kerja yang dilakukan dengan kualitas dan kuantitas yang sesuai untuk dicapai dalam pelaksanaan tugas dan tanggung jawab yang dibebankan kepada individu yang bersangkutan. Sedangkan kinerja perawat secara spesifik disampaikan oleh Kurniadih (2013) yang mengatakan bahwa kinerja perawat berhubungan langsung dengan tingkat produktivitas perawat itu senditi dalam memberikan asuhan keperawatan sesuai dengan tugasnya yang berdasarkan wewenang dan tanggung jawabnya sebagai seorang perawat. Maka dari itu jika seorang perawat dapat mengeluarkan suatu diagnosa yang tepat dan sesuai, maka hal tersebut akan sangat berguna bagi masyarakat luas. Hal tersebut kemudian akan menjadi salah satu indikator untuk menilai kinerja seorang perawat. 


\section{Metode}

Metode yang digunakan dalam penulisan jurnal ini adalah metode kualitatif dengan pendekatan kajian pustaka. Dalam penelitian ini data yang digunakan berasal dari sumber sumber dengan topik yang bersangkutan seperti dari jurnal keperawatan, buku, thesis, skripsi. Dalam arti lain dengan menggunakan kajian pustaka, maka apa yang dituliskan dalam jurnal ini merupakan hasil dari penelitian terdahulu yang membahas masalah yang sama. Dengan menggunakan metode kualitatif ini juga data yang disampaikan akan berbentuk penulisan dan penjabaran dan tidak dikemas secara statistik.

\section{Hasil}

Berdasarkan pemaparan tersebut, maka apa yang membuat diagnosa keperawatan berhubungan dengan kinerja perawat adalah karena dengan dikeluarkannya sebuah diagnosa keperawatan yang akurat, maka perawat tersebut memiliki tingkat produktivitas yang baik dalam menjalankan tugas dan kewajibannya sebagai seorang perawat. Maka dari itu penting bagi perawat untuk mampu memberikan diagnosa keperawatan yang akurat, karena salah satu tugas seorang perawat yang diharapkan oleh masyarakat luas adalah untuk menjamin kesejahteraan masayarakat dalam bidang kesehatan.

Meski berdasarkan penelitian yang dilakukan oleh Maimun (2016) yang mana dikatakan bahwa kinerja perawat di Indonesia masih rendah, namun hal tersebut tidak berarti tidak ada perawat di Indonesia yang memiliki tingkat produktivitas yang tinggi. Namun apa yang disampaikan oleh Maimun tersebut juga didukung oleh beberapa lainnya, antara lain dari hasil penelitian Hidayat Rahmat (2016) yang mengatakan bahwa kinerja perawat yang rendah masih menyentuh angka 50\% di rumah sakit Surabaya. Selain itu dari penelitian Maulani (2015) yang menyampaikan dari penelitiannya di RSUD H. Hanafie Muara Bungo Jambi dimana kinerja perawat rendah masih ada di angka 47,6\%. Angka - angka yang ditunjukkan dari berbagai hasil penelitian di berbagai kota di Indonesia tersebut juga tidak bisa dikatakan angka yang kecil. Yang berarti meski tidak semua perawat memiliki produktivitas yang buruk, namun perawat yang demikian masih lebih banyak dibandingkan dengan perawat yang produktif.

Maka dari itu penting bagi perawat untuk meningkatkan produktivitas dan lebih optimal dalam menjalankan tugas sebagai seorang perawat. Dengan demikian diagnosa keperawatan 
yang dibutuhkan oleh masyarakat luas juga dapat didapatkan oleh masyarakat tanpa adanya keraguan mengenai tingkat keakuratan diagnosa tersebut. Selain itu dengan diagnosa keperawatan yang tepat juga akan ditemukan solusi yang juga tepat untuk permasalahan yang menjadi inti dari diagnosa keperawatan tersebut. Diagnosa keperawatan juga dapat dikatakan lebih rumit dari diagnosa medis sendiri, sehingga dalam melakukan proses penyusunan diagnosa keperawtan diperlukan kinerja yang optimal.

\section{Pembahasan}

Diagnosa keperawatan dilakukan dan diberikan oleh perawat yang sudah memiliki lisensi dan berguna untuk menyatakan status kesehatan kliennya. Dengan mengeluarkan diagnosa keperawatan, maka status kesehatan seseorang dapat berubah sesuai dengan diagnosa keperawatan yang dikeluarkan. Maka dari itu seorang perawat yang mengeluarkan suatu diagnosa keperawatan tidak dapat melakukannya dengan tidak berdasar, melainkan harus berdasarkan suatu fakta yang ditemui setelah klien yang bersangkutan menjalani beberapa proses pemeriksaan kesehatan. Selain dikerjakan oleh perawat, diagnosa keperawatan secara keseluruhan juga sudah melalui keputusan klinik mengenai respon tiap - tiap individu yang bersangkutan dari berbagai kalangan masyarakat. Hal ini juga tentu dilakukan dengan teliti agar hasil yang dikeluarkan tepat.

Diagnosa keperawatan adalah hasil kerja seorang perawat dengan menentukan faktor faktor yang berhubungan dan faktor risiko yang berkemungkinan menjadi penyebab dari suatu masalah. Penyebab masalah yang dimaksud disini harus mengacu pada suatu kelompok data yang sudah ada. Diagnosa keperawatan juga secara garis besar dapat dikatakan lebih rumit dibandingan dengan diagnosa medis. Diagnosa keperawatan juga dapat dibedakan menjadi diagnosa keperawtan syndrome dan diagnosa keperawatan kolaborasi (Carpenito, 2001). Sedangkan menurut Herdman (2012), diagnosa keperawatan diberdakan menjadi diagnosa keperawatan aktual resiko, kemungkinan, dan kesejahteraan.

Sedangkan kinerja perawat adalah suatu produktivitas yang dilakukan oleh perawat dalam memberikan asuhan keperawatan, serta dalam menjalankan tugas dan kewajiban yang sesuai dengan wewenangnya. Kinerja perawat yang baik juga menjadi harapan masayrakat luas, karena secara umum peran perawat adalah untuk menjamin kesejahteraan khalayak umum dalam 
bidang kesehatan, baik dalam pengobatan, maupun mengenai pemberian informasi terkait kesehatan bagi masyarakat secara luas.

Diagnosa keperawatan adalah hasil kerja seorang perawat dengan menentukan faktor faktor yang berhubungan dan faktor risiko yang berkemungkinan menjadi penyebab dari suatu masalah. Penyebab masalah yang dimaksud disini harus mengacu pada suatu kelompok data yang sudah ada. Diagnosa keperawatan juga secara garis besar dapat dikatakan lebih rumit dibandingan dengan diagnosa medis. Diagnosa keperawatan juga dapat dibedakan menjadi diagnosa keperawtan syndrome dan diagnosa keperawatan kolaborasi (Carpenito, 2001). Sedangkan menurut Herdman (2012), diagnosa keperawatan diberdakan menjadi diagnosa keperawatan aktual resiko, kemungkinan, dan kesejahteraan.

Hubungan yang paling mendasar antara diagnosa keperawatan dengan kinerja perawat itu sendiri adalah mengenai bagaiman proses suatu diagnosa keperawatan hingga diagnosa tersebut dapat dikeluarkan. Diagnosa yang dikeluarkan merupakan diagnosa yang sudah menjadi keputusan klinik yang dimana selama proses pembentukan diagnosa tersebut dilakukan oleh perawat - perawat yang bersangkutan. Dalam hal ini perawat harus optimal dalam menjalankan tuganya agar diagnosa keperawatan yang diberikan bersifat akurat. Hal tersebut harus secara mutlak dilakukan karena dengan dikeluarkannya sebuah diagnosa keperawatan, maka status kesehatan klien yang bersangkutan dapat berubah sesuai dengan hasil diagnosa keperawatan yang dikeluarkan tersebut.

Maka dari itu apabila seorang perawat yang bertugas membuat hasil diagnosa keperawatan seorang klien tidak bekerja dengan optimal, maka yang dikhawatirkan adalah keluarnya sebuah diagnosa salah yang tidak akurat dan tidak mendasar. Apabila hal ini terjadi maka bukan hanya klien yang bersangkutan yang dirugkikan, namun juga perawat yang bersangkutan beserta dengan rumah sakit tempat perawat tersebut menjalankan tugasnya. Seperti yang juga sudah dijabarkan diatas mengenai persentase kinerja perawat rendah yang masih menyentuh hampir setengah dari keseluruhan perawat di kota atau rumah sakit yang bersangkutan, maka dapat diketahui bahwa di Indonesia sendiri kinerja perawat memang masih rendah di sebagian besar daerah di Indonesia. 
Selain itu, kinerja perawat pada dasarnya di dipengaruhi oleh beberapa faktor. Tiga variabel yang dapat mempengaruhi kinerja perawat sebagai individu adalah variabel individu itu sendiri. Artinya kemampuan dan keterampilan seorang perawat sebagai individu perlu dioptimalkan agar dapat memiliki kinerja yang baik dan juga optimal karena memiliki kemampuan dan keterampilan yang mendukung untuk menjalankan tugas dan kewajibannya sebagai seorang perawat. Yang kedua adalah variabel psikologi yang terdiri dari persepsi, sikap, kepribadian, belajar, dan motivasi. Artinya seorang perawat perlu memenuhi semua faktor tersebut agar dapat memiliki kinerja yang baik. Misalnya motivasi, seorang perawat harus memiliki motivasi yang jelas dalam menjalankan tugasnya agar apa yang dilakukan sebagai seorang perawat memiliki tujuan yang jelas sehingga akan berpengaruh langsung dengan kinerja yang dihasilkan. Variabel ketiga adalah variabel organisasi yang terdiri dari sumber daya, kepemimpinan, imbalan, struktur, dan desain pekerjaan (Gibson, 2008). Berbeda dengan variabel individu, yang dimaksud dengan variabel organisasi ini adalah kemampuan perawat untuk memahami struktr pekerjaan serta kemampuan untuk bekerja dalam lingkup organisai, bukan hanya secara individu.

Sedangkan hal lain disampaikan oleh Ilyass (2013) yang berpendapat bahwa kinerja perawat dipengaruhi oleh beberapa faktor berikut, antara lain adalah usia, jenis kelamin, pengalaman, orientasi dan gaya komunikasi, motivasi, pendapatan dan gaji, lingkungan, organisasi, supervisi dan pengembanga karir. Berdasarkan apa yang disampaikan mengenai faktor dan variabel yang mempengaruhi kinerja perawat tersebut, juga berhubungan langsung dengan hal - hal yang harus dimiliki oleh perawat agar dapat membuat diagnosa keperawatan yang akutal. Hal ini menjadi jawaban lainnya mengenai apa hubungan antara diagnosa keperawatan dan kinerja perawat itu sendiri.

Berdasarkan fungsi dari diagnosa keperawatan itu sendiri yang mana adalah untuk memungkinan perawat dalam menganalisis dan mensintesis data yang telah dikelompokkan dari hasil diagnosa keperawatan tersebut. Selain itu diagnosa keperawatan sendiri juga dapat digunakan untuk mengidentifikasi suatu masalah kesehatan yang ada, seperti apa faktor dari masalah tersebut, apa penyebab permasalahan tersebut, hingga untuk menentukan kemampuan klien yang bersangkutan dalam mencegah serta memecahkan masalah tersebut. Maka dari itu, sebuah diagnosa keperawatan hanya dapat tersusun apabila perawat yang bersangkutan memiliki 
kinerja yang baik dan optimal. Apabila tidak, meski ada diagnosa keperawatan yang dikeluarkan, namun ketepatan datanya akan diragukan meski hanya sebuah diagnosa.

\section{Penutup}

Setelah pemaparan mengenai hubungan antara diagnosa keperawatan dengan kinerja perawat yang sudah disampaikan diatas, maka sudah terlihat apa hubungan dari kedua hal tersebut, yaitu adalah karena kedua hal tersebut merupakan hal yang saling mempenharuhi satu sama lain. Maksudnya adalah diagnosa keperawatan yang dikeluarkan oleh perawat dapat dijadikan indikator penilaian kinerja perawat yang bersankutan dengan melihat tingkat keakuratan dari diagnosa tersebut. Dalam arti lain kinerja perawat yang optimal lah yang akan menghasilkan sebuah diagnosa keperawatan yang akurat. Apabila kinerja perawat tidak optimal, maka diagnosa keperawatan yang diekluarkan tersebut diragukan keakuratan datanya. Maka dari itu dikatakan bahwa kedua hal tersebut merupakan hal yang memang saling bersangkutan dan tidak dapat dipisahkan satu sama lain, meksi kinerja perawat tidak hanya dilihat dari diagnosa keperawatan karena ada beberapa faktor lainnya, namun seorang perawat yang dapat memenuhi faktor lainnya, kemungkinan besar merupakan perawat yang memiliki tingkat produktivitas yang tinggi. 


\section{Daftar Pustaka}

Ali Z. (2002). Dasar-dasar Keperawatan Profesional. Jakarta: Widya Medika.

Asi, S.P. (2013). Pengaruh Iklim Organisasi dan Burnout terhadap Kinerja Perawat RSUD dr. Doris Sylvanus Palangka Raya. Jurnal Aplikasi Manajemen, Volume 11, Nomor 3. 515-516.

Bawalu, T. (2019). TIPE-TIPE DIAGNOSA KEPERAWATAN YANG PENTINGDIKETAHUI OLEH PERAWAT DAN MAHASISWAKEPERAWATAN. 2 - 5.

Hidayat, A. Aziz Alimul. 2007. Pengantar Konsep Dasar Keperawatan, Edisi 2. Jakarta: Salemba Medika.

Kurniawati,D., \& Solikhah. (2012). Hubungan Kelelahan Kerja dengan Kinerja Perawat di bangsal rawat inap Rumah Sakit Islam Fatimah Kabupaten Cilacap, KES MAS, vol.6, no.2

Mandagi, F. M., Umboh, J. M., \& Rattu, J. A. (2015). ANALISIS FAKTOR - FAKTOR YANG BERHUBUNGAN DENGANKINERJA PERAWAT DALAM MENERAPKAN ASUHAN KEPERAWATAN DI RUMAH SAKIT UMUM BETHESDA GMIM TOMOHON. Jurnal $e$ Biomedik $(e B m), 884$ - 885 .

Potter \& Perry. (2005). Buku Ajar Fundamental Keperawatan, Konsep, Proses, dan Praktek. (Edisi 2 ed.). Jakarta: EGC

Rudianti, Y., Handiyani, H., \& Sabri, L. (2013). PENINGKATAN KINERJAPERAWAT PELAKSANA MELALUI KOMUNIKASI ORGANISASI DIRUANG RAWAT INAP RUMAH SAKIT. Jurnal Keperawatan Indonesia , 25 - 26.

Simamora, R. H. (2019). Socialization of Information Technology Utilization and Knowledge of Information System Effectiveness at Hospital Nurses in Medan, North Sumatra. Editorial Preface From the Desk of Managing Editor..., 10(9).

Simamora,R.H., Bukit, E., Purba, J. M., \&Siahaan, J. (2017). Penguatan kinerja perawat dalam pemberian asuhan keperawatan melalui pelatihan ronde keperawatan di rumah sakit royal prima medan. Jurnal pengabdian kepada masyarakat, 23(2), 300-304.

Yahya, S. (2013). Pengaruh Kualitas Pelayanan Keperawatan Terhadap Kepuasan Pasien di Ruang Rawat Inap Terpadu (Rindu) RSUP H. Adam Malik Medan. Jurnal Universitas Sumatera Utara.

Yanti, R. I., \& Waristo, B. E. (2013). Hubungan Karakteristik Perawat, Motivasi, Dan Supervisi Dengan Kualitas Dokumentasi Proses Asuhan KeperawatanRetyaningsih Ida Yanti, Bambang Edi Warsito107HUBUNGAN KARAKTERISTIK PERAWAT, MOTIVASI, DAN SUPERVISI 


\section{DENGAN KUALITAS DOKUMENTASI PROSES ASUHAN KE. Jurnal Managemen}

Keperawatan, 107 - 108. 